SF 201

A5

Copy 1

The Effect of the Age of Sire and Dam on Offspring in Dairy Cows

\author{
C. L. ALLEN
}

Reprinted withoul change of paging, from the Journal of Beredily (Organ of the American Genetic Association), Vol. XIII, No.4; Wash. ington, D.C., A pril. 1922. 



\title{
THE EFFECT OF THE AGE OF SIRE AND DAM ON THE QUALITY OF OFFSPRING IN DAIRY COWS
}

\author{
A THESIS \\ PRESENTED TO THE FACULTY OF THE GRADUATE SCHOOL \\ OF CORNELL UNIVERSITY IN PARTIAL FULFILLMENT \\ OF THE REQUIREMENTS FOR THE DEGREE OF \\ DOCTOR OF PHILOSOPHY
}

BY

CHARLES LORING ALLEN

)

1920

Reprinted from THE JOURNAL OF HEREDITY (Organ of the American Genetic Association), Vol. XIII, No. 4 ; Washington, D. C., April, 1922. 


$$
\begin{aligned}
& \text { SF } 20^{\circ} \\
& A^{5}
\end{aligned}
$$

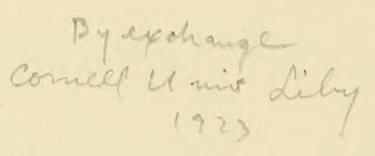

$\because$ 


\title{
THE EFFECT OF THE AGE OF SIRE AND DAM ON THE QUALITY OF OFFSPRING IN DAIRY COWS
}

\author{
C. L. Allex \\ Cornel!. University, Ithaca, N. Y.
}

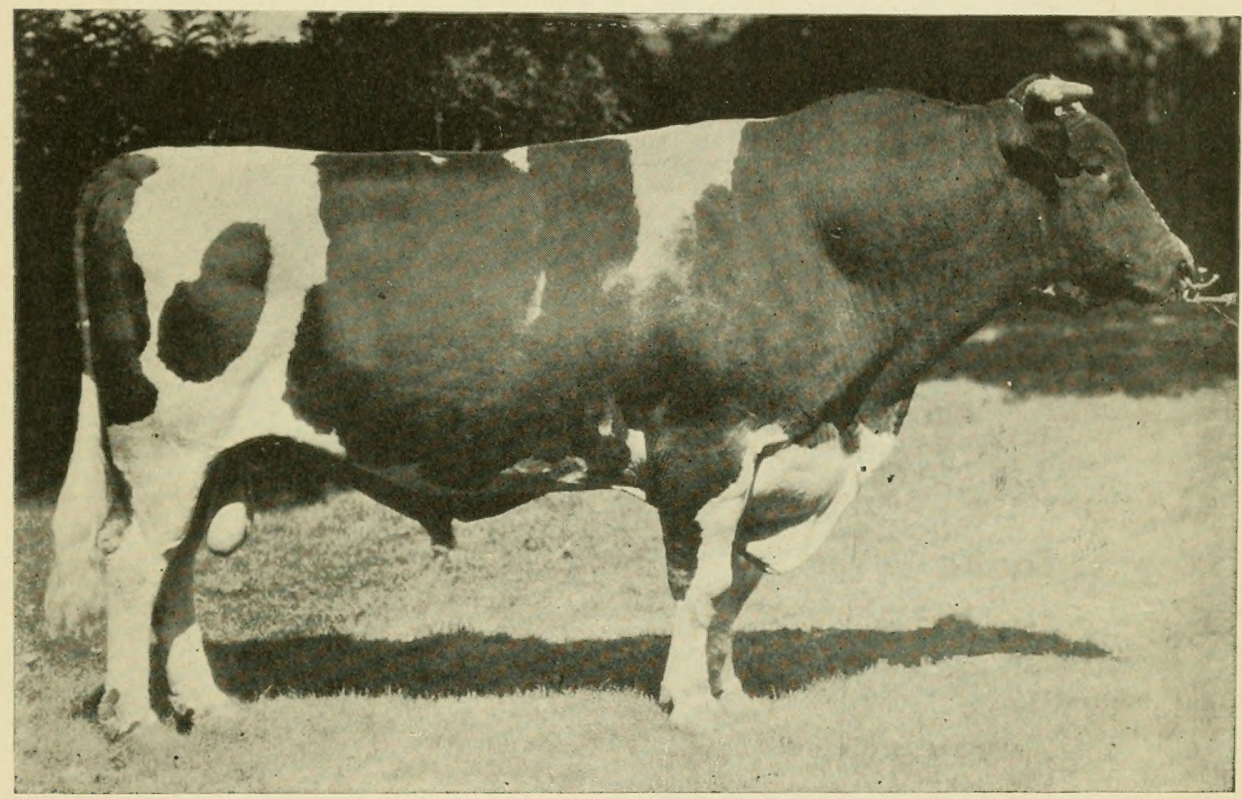

\section{A FAMOUS HOLSTEIN SIRE}

Figure 10. Ormsby Korndyke Lad (102469) one of the great sires of the Holstein Friesian Breed. His daughters are noted for their high production records for both 7 day and yearly work. He has 18 daughters with records of over 30 pounds of butter ( $80 \%$ fat) in 7 days. He also has 14 daughters with records of over 1000 pounds of butter $(80 \%$ fat $)$ in one year. The sire of Ormsby Korndyke Lad was only 23 months of age when he was born and his dam was just a little over 4 years of age (51 months). Photograph from Holstein Friesian World.

1

HE effect of the age of parents on the quality of the offspring is in a large measure concerned with the ideá of cumulative inheritance, particularly if we do not consider the matter of the proven sire or dam. If an animal is a more valuable parent after it has attained maturity, it is more valuable for one of two reasons. Either the mature animal must be able, merely because of its full physical development better to im- press its characters on its offspring, or the mature animal must in the process of attaining maturity, have become endowed with something, due to training or environment, which it can transmit to its progeny. After a century of study, this matter is far from settled and the question as to the possible effect of environment on the transmission of a tendency to increase or decrease certain quantitative functions is still important. 


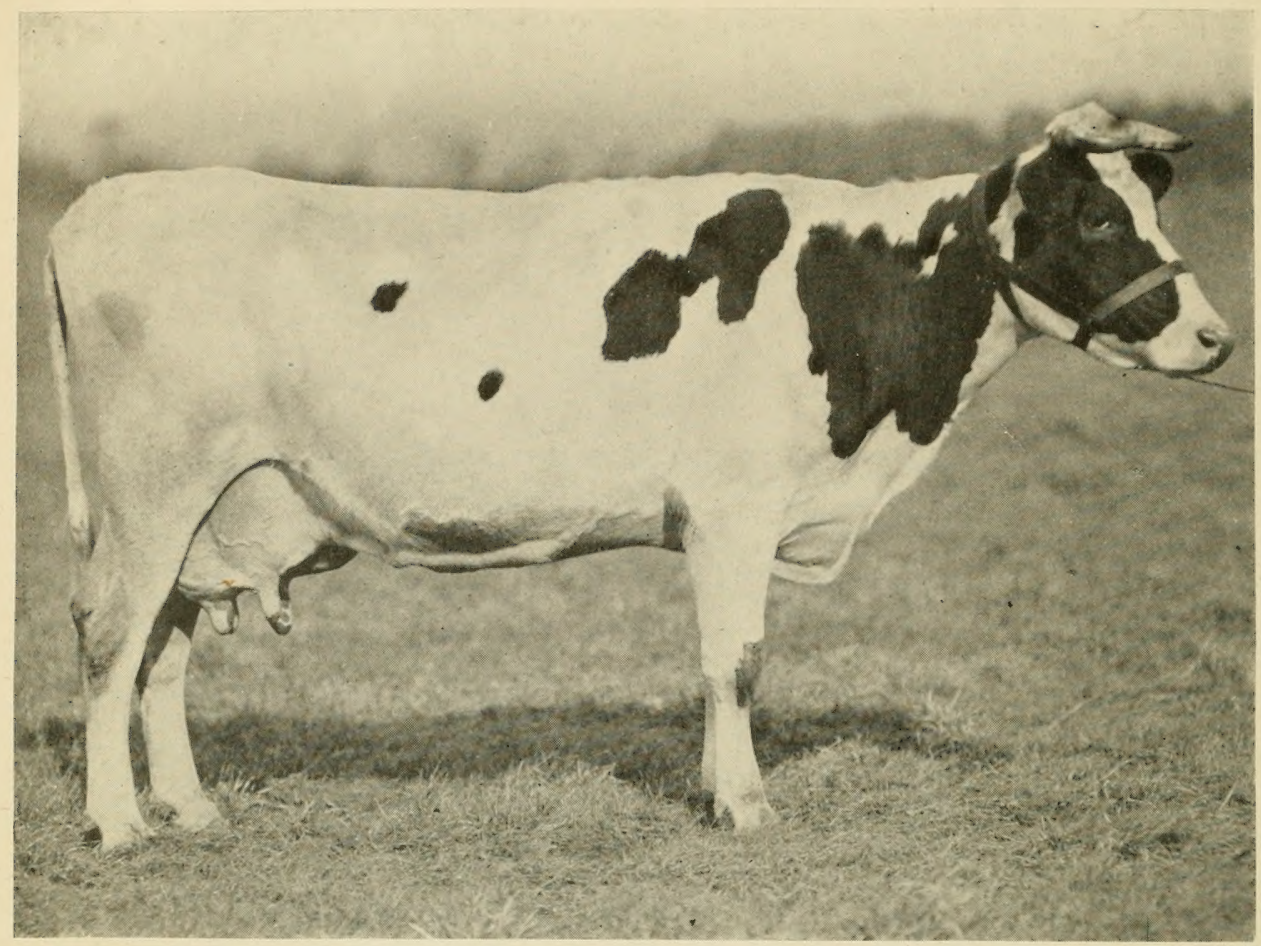

JOHANNA DE KOL CONCORDIA

FigurE 11. At three and a half years of age her record was 19037 pounds of milk and 671 pounds of butterfat. Her sire, Sir Clothilde Concordia, was two years nine months of age when she was born, while her dam, Cold Spring Johanna De Kol 2nd, was three years and a half old. The great number of cases where the parents of high producing cows are as young, or younger than these, leaves no doubt that the off-spring of immature parents are just as good producers or transmitters of production as those born when the same parents are mature. Photo by U. S. Department of Agriculture. (See text, p. 173. .)

In practical breeding, it would be very advantageous to know definitely whether the young born of immature parents are as valuable for production, and for reproducing their kind, as those born of more mature parents. It is the aim of this paper to show whether the parentage of a group of high producing or superior cows averages older than the parentage of a group of comparatively low producing or inferior cows. The paper also attempts to show the percentage distribution of offspring for the various ages of both sire and dam; the age when cows actually make their best records; and whether the offspring of very young or very old animals are inferior.

\section{METHOD}

The data reported in this paper were taken from Volume 27 of the Advanced Registry Year book and the Herd Books of the Holstein Friesian Association of America.

The superior class of animals chosen include those that up to April 30th, 1916, had made records of 24 pounds or more of butterfat in seven days. This included all of the so-called thirty pound cows since 24 pounds of butterfat is equal to 30 pounds of eighty percent butter. For purposes of more careful study, this class was divided into three groups as follows:

Group I-All cows producing over 27.3 pounds of butterfat in 7 days. 
Group II-All cows producing between 25.6 and 27.3 pounds of butterfat in 7 days.

Group III-All cows producing between 24.0 and 25.6 pounds of butterfat in 7 days.

The comparatively inferior class of animals chosen includes all of the socalled mature cows, that is, cows five years of age or over, that produced less than fourteen pounds of butterfat in seven days and were entered in the 27th Volume of the Holstein Friesian Advanced Registry Year Book as entries or re-entries. This class was divided into three groups that were fairly comparable in numbers to the groups of the superior class, as follows:

Group I-All cows producing between 12 and 12.5 pounds of butterfat in 7 days.

Group II-All cows producing between 12.5 and 13.0 pounds of butterfat in 7 days.

Group III - All cows producing between 13.0 and 14.0 pounds of butterfat in 7 days.

The groups were arranged so that the very highest producers were in group 1 of the Superior Class and the very lowest producers were in group 1 of the Inferior Class. Then, if there was any difference in age, it was thought that the first groups should be further apart than the second and third groups.

The 7 day record was chosen as the basis for this study because a larger number of records were available and the 7 day record is generally recognized as a valuable method of determining the productive ability of dairy cows.

Three generation pedigrees were compiled for all the cows of both the Superior and Inferior Classes. These pedigrees included the date of birth for all animals in every pedigree. This makes it possible to compute the difference in age between any animal and its parents and tells us the age of the parents at the time the animal in question was born. This also provides data for determining the average difference in age between generations, and allows the calculation of the percentage distribution of offspring according to the age of parents, making it possible to observe whether more good cows or poor cows are born from very young or very old dams. The difference in age between parent and offspring was computed in months to the nearest month.

In order to determine at what age the superior cows made their records, it was necessary to take this data directly from the Advanced Registry Year book and record it on the pedigree.

\section{RESULTS-THE DIFFERENCE IN AGE COMPARED}

Table I gives the average age of the ancestry of the Superior and the Inferior Classes by groups and for the classes

TABLE I. Average Age, in Months, of Ancestry of Superior and of Inferior Classes of Cows

\begin{tabular}{|c|c|c|c|c|c|c|c|c|}
\hline \multirow[b]{2}{*}{ Ancestor } & \multicolumn{4}{|c|}{ Superior Cows } & \multicolumn{4}{|c|}{ Inferior Cows } \\
\hline & Group 1 & Group 2 & Group 3 & Class & Group 1 & Group 2 & Group 3 & Class \\
\hline Sire. . & 44.3 & 51.7 & 46.3 & $47.1 \pm .647$ & 45.7 & 44.6 & 41.6 & $43.1 \pm .529$ \\
\hline 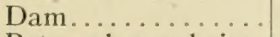 & 62.8 & 63.6 & 61.2 & $61.9 \pm .890$ & 60.0 & 62.2 & 64.7 & $63.1 \pm .941$ \\
\hline Paternal grand sire. & 48.6 & 49.6 & 49.6 & $49.5 \pm .717$ & 45.4 & 46.4 & 46.7 & $46.6 \pm .646$ \\
\hline Paternal grand dam. & 64.9 & 65.2 & 67.6 & $66.7 \pm .929$ & 66.5 & 69.4 & 65.8 & $66.7 \pm 1.034$ \\
\hline Maternal grand sire. & 42.3 & 41.4 & 42.3 & $42.1 \pm .507$ & 44.8 & 43.0 & 43.4 & $43.6 \pm .508$ \\
\hline Maternal grand dam & 65.2 & 63.0 & 59.6 & $61.0 \pm .873$ & 65.0 & 69.4 & 62.8 & $64.7 \pm 1.013$ \\
\hline Great grand $\operatorname{sir}^{1} \ldots$ & 44.3 & 44.8 & 48.1 & $46.9 \pm .640$ & 45.4 & 47.9 & 43.8 & $45.1 \pm .602$ \\
\hline Great grand dam ${ }^{1}$. . & 61.3 & 59.0 & 63.8 & $62.5 \pm .939$ & 61.7 & 72.1 & 64.7 & $65.7 \pm 1.006$ \\
\hline $\begin{array}{r}\text { Number of pedigrees } \\
\text { in each group and } \\
\text { class................ }\end{array}$ & 86 & 121 & 404 & 611 & 111 & 114 & 285 & 510 \\
\hline
\end{tabular}

${ }^{1}$ Great grand sire refers to sire of paternal grand sire. Great grand dam refers to the dam of the maternal grand dam. 
as a whole. This table allows us to make comparisons and determine any significant difference between the average age of the superior cows and the (comparatively) inferior cows.

It will be noted in table I that the greatest difference in age is four months and that this occurs in the case of the sires. This difference might seem to be somewhat significant in the light of the probable error as a measure of its probable significance. The difference is more than three times the probable error but the probable error in this case is small. We must remember, however, that four months is not a very marked difference and this difference loses a large part of its significance when we study the group averages. There is more difference between the groups within the classes even here than there is between the classes themselves. This is still more noticeable in other places in the table where the class difference is not so great. Take for example, the case of the dams, the great granddams, or the maternal grand sire. In each of these cases, the difference is probably insignificant in the light of the probable error, and in each case, the difference between the groups within the class is greater than the difference between the classes.

The real difference in age between the various parents and generations is more clearly shown by means of a pedigree. Such a pedigree is given in Figure 12.

It is evident that there can be no increased hereditary value due to the age of the dams, for in every case except one, the dams of the Inferior Class average older, though not significantly so, than the dams of the Superior Class. In the one case, that of the paternal granddam, they average exactly alike.

From a study of Table I and the pedigree, Figure 12, it is apparent that there is no significant difference between the ages of parents of the Inferior and of the Superior Classes. In only one case is the difference outside the limits defined by three times the probable error. In this case, the small difference between the class averages can hardly be considered significant when there is so great a difference between the group averages within the class.

\section{BULLS ARE NO MORE VALUABLE PARENTS AS THEY GROW OLD}

Turning our attention again to the pedigree, Figure 12, we note that in every case the Superior sires on the top line of the pedigree are older than the corresponding inferior sires. The difference is probably not significant even in the case of the sires, but the tendency persists.

This led to a study to determine whether a bull produced superior offspring as he grew older. From a study of four bulls having a total of five hundred and six daughters, it seems that bulls may or may not have better daughters as they grow older, depending on the quality of animals to which they are bred. As a bull proves his superior worth, he is very likely to be bred to better cows and produce better offspring. This probably accounts for the difference shown in the pedigree. This whole matter will be fully discussed in a later paper. Thus the difference in age of sires can be very readily assigned to the use of the sires and there is no indication that the sires are any better when they are old than when young and immature. In fact the frequency distribution, Figures 13 and 14 , tends to show that the young parent of either sex is just as valuable as a parent when immature as it is in later life. The frequency curves include only the sires and dams of the first generation.

\section{FREQUENCY DISTRIBUTION ACCORD- ING TO AGE OF SIRE}

In the frequency curves, Figures 13 and 14, it will be observed that the curves run very nearly parallel throughout. The curves start high, indicating that a large percentage of cows in both the Superior and Inferior Classes are sired by very young bulls. In this connection, it will be remembered from Table I that 


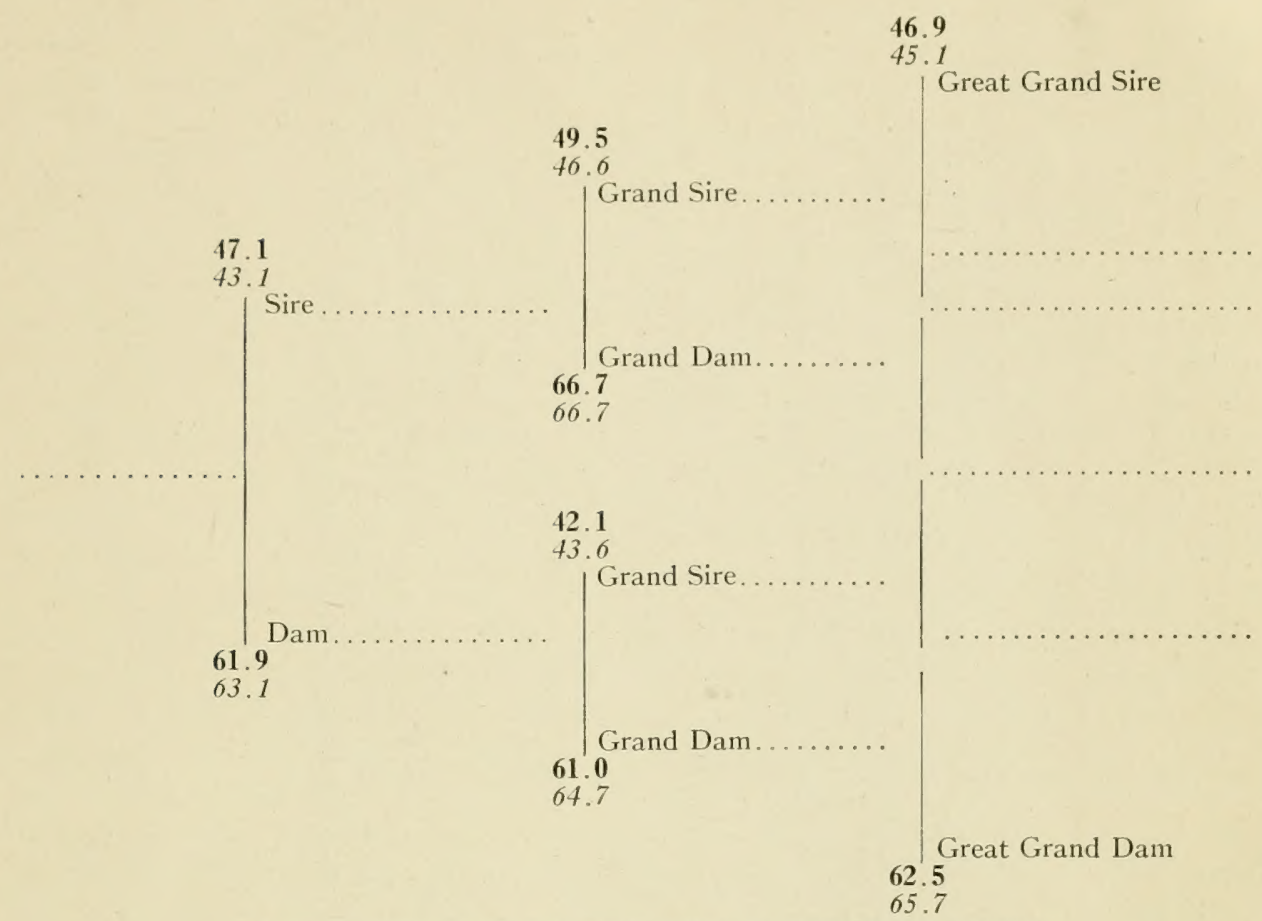

\section{AN AGE-PEDIGREE OF THE TWO CLASSES OF COWS}

FIGURE 12. This shows the average age of the ancestors of the superior cows (Bold-face type), and of the inferior cows (Italics). It is evident that there are no significant differences in the age of the forebears of the two classes. (See text, p. 169.)

the sires of the Superior Class average less than four years of age, 46.4 months to be exact, and that the sires of the Inferior Class average somewhat younger. The largest number of offspring were born when their sires were from two and one-half to three years of age. This means that these bulls sired a larger percentage of their offspring between twenty-two and twentyseven months of age than at any other time.

Table II shows very clearly just how our purebred sires are used. It indicates that improvement has been based on the selection of young sires rather than on the use of tried sires.

\section{THE PROVEN SIRE}

A bull cannot be called a proven sire until his first crop of heifers come in milk and can hardly be so called until these heifers have milked at least one year. Thus a bull can hardly be called a proven sire until he is five years of age. In general practice, the percentage of cows sired by unproven bulls is probably much higher than the percentage shown for the animals included in this study. This means that even the breeders who are making records use a tried sire for only a small percentage of their cows. That the tried sire is more valuable is indicated by the fact that 21.1 percent of the Superior cows are daughters of tried sires, whereas only 15.9 percent of the Inferior cows are daughters of bulls of an equal age. This may seem to conflict with the idea that the bull when old is not more valuable, but the paper referred to above shows that he is not more valuable as a parent.

\section{FREQUENCY DISTRIBUTION ACCORD- ING TO AGE OF DAM}

The frequency curve for the dams, Figure 13 , is very much more irregular than the curve for the sires but on the 


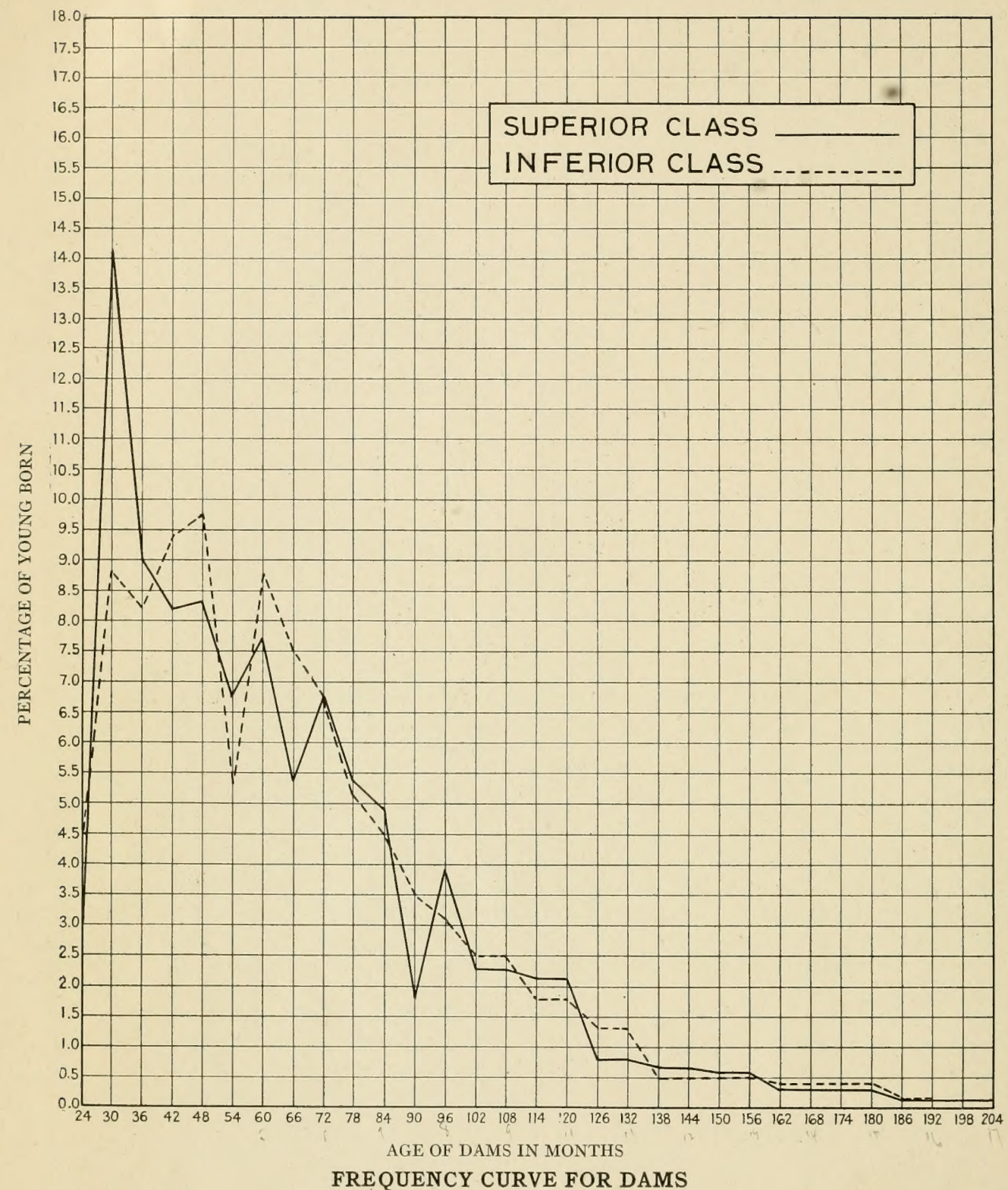

Figure 13. The percentage of young born by dams of various ages is shown in this chart. The age of the dams is computed for six-months periods, and the upper age limit of these groups is shown. That is, all the dams 24 months and under are considered 24 months old, those between 24 and thirty months of age, as 30 months old, etc. It is evident that much the greater number of calves are born by very young cows, the quality of whose offspring cannot be known. (See text, p. 171.) 
whole, even here, the curves run nearly parallel. There is, however, a distinctly larger percentage of high producers born of very young dams than there is of low producers. It is hard to account for this unless the Superior Class have received better care and are bred younger on the average than the Inferior Class.

It will be noted in connection with Table III that a slightly larger percentage of the Superior Class were born from dams under five years of age than there were of the Inferior Class. In later life, the two classes are very nearly alike and almost exactly as many of the Superior Class were born from dams over eight years of age as were born in the Inferior Class from dams of a like age. The percentage having dams over twelve years is exactly alike for both classes.

VALUE OF OFFSPRING OF VERY YOUNG

$$
\begin{gathered}
\text { AND VERY OLD } \\
\text { PARENTS }
\end{gathered}
$$

From a study of the frequency curves and Tables II and III, it is evident that the young born from very young parents or from very old parents are as valuable as any for productive

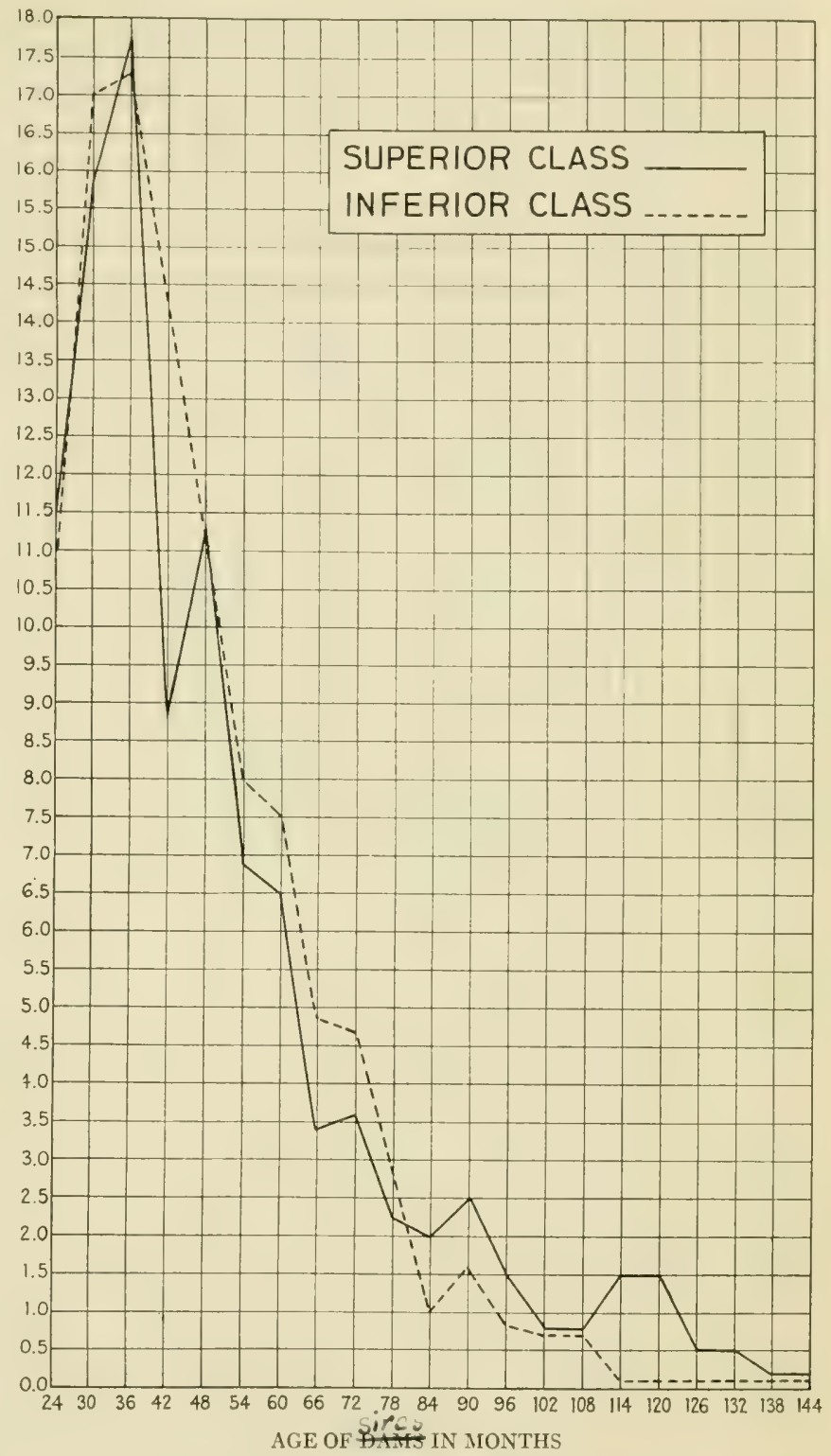

FREQUENCY CURVE FOR SIRES

FIGURE 14. The co-ordinates are the same as in the preceding chart. The same conclusions apply even more strikingly in this case, as the sires are not used for breeding purposes as long as the dams. A sire cannot be considered a proven sire until his first crop of daughters have been in milk at least a year, which means that he must be five years of age. These figures are for a selected class of sires and show that even the breeders who are making records use tried sires for only a small percentage of their cows. (See text, p. 170.) 


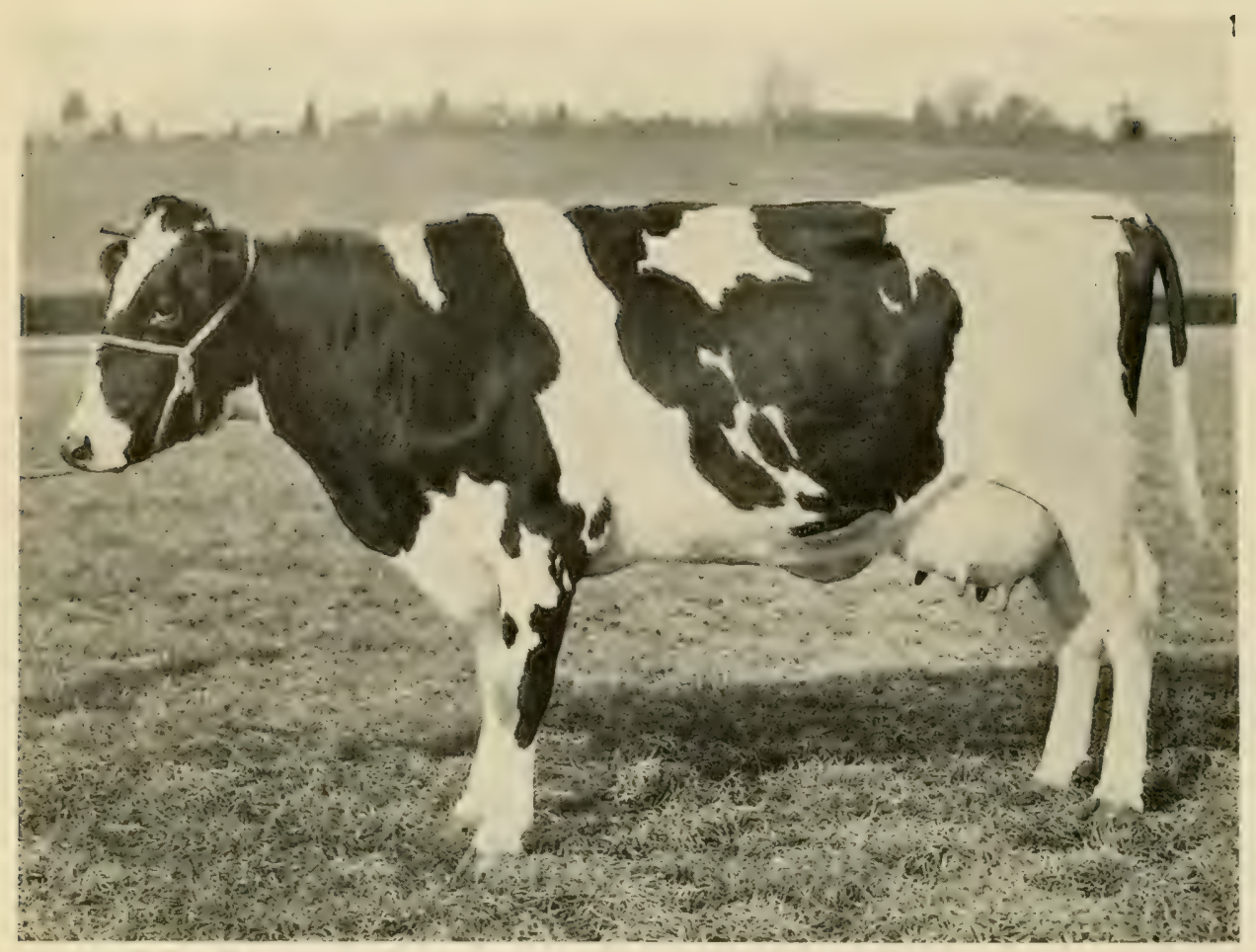

WATSON SEGIS PONTIAC HOMESTEAD

FIGURE 15. She was born when her dam, Watson Segis Pontiac, was just 2 years, 2 days old, when her sire, Piebe Laura Allie Homestead King, was a senior two-year-old. Her record is 25,360 pounds of milk and 928 pounds of fat. Her mother has a record of 844 pounds of fat, and she is the daughter of King Segis Pontiac Count, a great breeding sire, who was only a little over two years old when she was born. Photo by U.S. Department of Agriculture.

TABle II. The Percentage of Daughters Born on or before a Given Age of Sire, and the Age of the Sire at the Time the Dams of the Daughters were Bred

\begin{tabular}{|c|c|c|c|}
\hline \multirow{2}{*}{$\begin{array}{c}\text { Age of Sire when Daughters } \\
\text { were born }\end{array}$} & \multirow{2}{*}{$\begin{array}{l}\text { Age of Sire when the Dams of } \\
\text { Daughters were Bred }\end{array}$} & \multicolumn{2}{|c|}{ Percentage of Daughter } \\
\hline & & Superior & Inferior \\
\hline $\begin{array}{l}30 \text { Months and Under } \\
36 \text { Months and Under } \\
60 \text { Months and Under } \\
\text { Over } 60 \text { Months }\end{array}$ & $\begin{array}{l}21 \text { Months and Under } \\
27 \text { Months and Under } \\
51 \text { Months and Under } \\
\text { Over } 51 \text { Months }\end{array}$ & $\begin{array}{l}27.5 \\
45.3 \\
78.9 \\
21.1\end{array}$ & $\begin{array}{l}28.0 \\
45.3 \\
84.1 \\
15.9\end{array}$ \\
\hline
\end{tabular}

Table III. Showing the Percentage of Young Born Before and After a Given Age of Dam

\begin{tabular}{|c|c|c|}
\hline $\begin{array}{c}\text { Age of Dam when Daughters } \\
\text { were born }\end{array}$ & $\begin{array}{c}\text { Percentage of Superior } \\
\text { Daughters }\end{array}$ & $\begin{array}{c}\text { Percentage of Inferior } \\
\text { Daughters }\end{array}$ \\
\hline 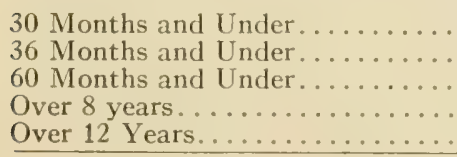 & $\begin{array}{r}17.2 \\
26.2 \\
57.1 \\
14.8 \\
2.8\end{array}$ & $\begin{array}{r}13.3 \\
21.6 \\
54.9 \\
15.0 \\
2.8\end{array}$ \\
\hline
\end{tabular}




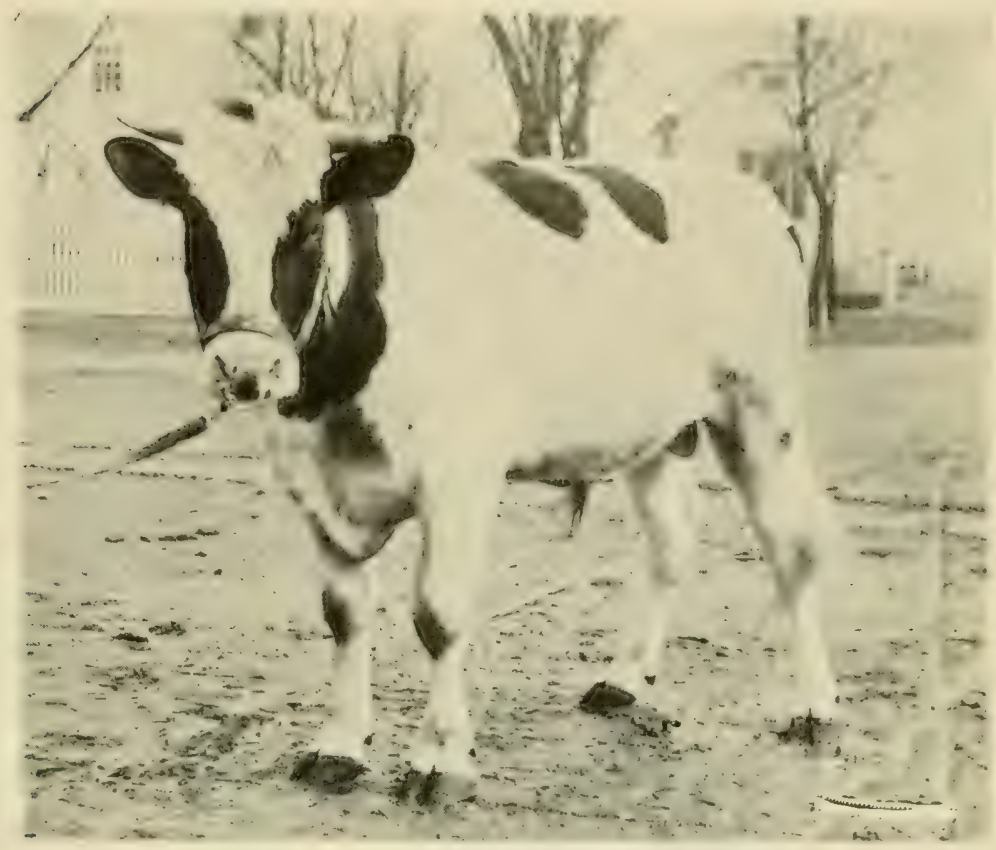

\section{A SIRE OF RECORD-MAKING DAUGHTERS}

Figure 16. King Hengeveld Aaggie Fayne (56635) has shown remarkable ability to transmit production. He was slaughtered when only three years of age and as a result has only $31 \mathrm{~A} . \mathrm{R} . \mathrm{O}$. daughters. Eleven of these daughters have records in excess of 30 pounds of butter $(80 \%$ fat) in 7 days. Four of his daughters have yearly records. Three of these records made by two and three year old heifers average $21,762.2$ pounds of milk and 978.93 pounds of butterfat. The other yearly record was made by a mature daughter and is $15,486.1$ pounds of milk and 530.89 pounds of butterfat.

King Hengeveld Aaggie Fayne was born when his parents were quite young. His sire was 22 months of age and his dam 28 months of age when he was born. Photo by the Holstein-Fresian World.

purposes. An unusually large percentage of the Superior Class were born before their dams were two and onehalf years of age and must have been first calves. The sires of a large percentage of the Superior Class were also under two and one-half years when the dams were bred. On the other hand, just as large a percentage of the Superior Class as of the Inferior Class is from very old parents.
AGE WHEN THE BEST RECORDS ARE MADE

Table IV was arranged for the Superior Class only. The best record was used in every case. If any of the cows herein considered have made a better record since the collection of this data this fact introduces an error. It is recognized that only a very few cows have ever made more than one

TABLE IV. The Average Age of All the Superior Cows at the Time Their Records Were Made

\begin{tabular}{l|c|c|c|c}
\hline \hline & Group I & Group II & Group III & Superior Class \\
\cline { 1 - 4 } Number of Cows........ & 86 & 121 & 404 & 611 \\
Average Age in Months. & 69.7 & 72.1 & 73.7 & 72.2 \\
\hline
\end{tabular}


record above thirty pounds of butter in a week and most of those that have done so are here considered. This error, then, is in all probability very small.

The group averages and the class average all show that the best records of the animals herein considered were made at an average age of about six years. Of course many were much older than this and many were younger, but it is well known that animals vary greatly in rapidity of development. It would seem that the numbers considered are large enough to make the average significant even though it is recognized that most cows do not have a chance to make a record every year. The cow is most likely to be tested at the time she shows greatest promise. Since these high producers made their best records at six years of age, it seems only fair to assume that they were at the height of their productive capacity at this time. It would also indicate that cows generally reach the limit of their possibilities for high production at about this age. This contention is supported from other sources, ${ }^{1}$ although one investigator, ${ }^{2}$ who attacked the problem in an entirely different manner, maintains that the highest production is not reached until much later in life.

\section{SUMMARY}

The parentage of superior or high producing dairy cows is no older than the parentage of comparatively inferior or low producing cows and thus the old animal is no more valuable as a parent than the young animal.

As far as the age of either parent is concerned, the young born at one time in life seem to be just as valuable as the young born at any other time.

A very large percentage of our cows are born of immature parents but the proven animal at any age is much more valuable for breeding purposes.

On the average, cows make their best records at about six years of age.

${ }^{1}$ Pearl Raymond, The Change of Milk Flow with Age. Maine Agricultural Experiment Station Bulletin, No. 262. 1917.

${ }^{2}$ Gowan, J. W., Studies in Milk Secretion VIII. Maine Agricultural Expiriment Station Bulletin, No. 293. 1920. 


LIBRARY OF CONGRESS

|||||||||||||||||||||||||||||||||||||||||||||

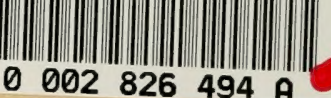

